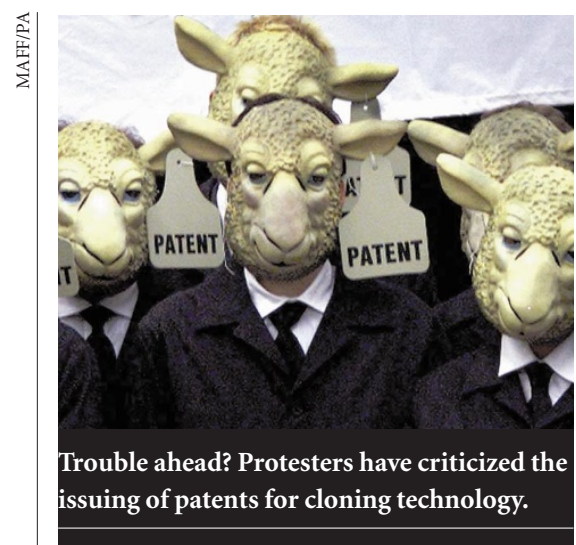

$>$

identical embryonic stem cell from a patient's own cell, then to cause the cell to differentiate into the kind needed for therapy - pancreatic cells in diabetes, for instance, or dopamine-producing neurons in Parkinson's disease. The potential therapeutic applications leave Earp "excited". "There are huge medical advances at our fingertips," he says.

The patents were criticized last week from various sides. "Organizations, including charities, may not have the money to pay to use this patent technology," Vivienne Nathanson, head of science and ethics at the British Medical Association, told BBC Television. "So this could inhibit medical research."

"It's going to break the health-care system," adds Jeremy Rifkin, who heads the Washington-based Foundation on Economic Trends. "If Geron and Roslin can get a lock on stem cells and [cloned] embryonic cells, they then have total control over future medical developments in this area of research."

Rifkin says he is distressed by the UK patent office's "chilling" and

"unconscionable" decision to grant a patent on the earliest form of human life. He argues that patents should pertain only to inventions, not to naturally existing entities, such as humans. The decision, he says, is "an absolutely transparent violation of the patent statutes in virtually every country. This is something my attorneys are going to move on immediately with formal legal protests in the UK."

But Arthur Caplan, director of bioethics at the University of Pennsylvania, says Roslin has rightfully won the patents. "They've got the products and the uses as well as the technique." He adds: "It's time to shift the issue to a discussion of what responsible [patent] ownership is."

Geron's Earp says the company has "absolutely no intention" of inhibiting medical research. "We want to openly encourage as many people as possible to do basic research" using cloning and stem-cell technologies. Meredith Wadman

\title{
US survey reveals location of human tissue samples
}

\section{Washington}

A survey to be published next week will show the whereabouts of more than 300 million human tissue samples archived in the United States. The survey's authors hope it will form the basis for a comprehensive database of samples and increase their availability to the growing army of researchers who need them.

The Handbook of Human Tissue Resources, to be published by the Science and Technology Policy Institute at the Rand Corporation, attempts to provide comprehensive information on the hundreds of human tissue archives. These range from tens of millions of samples held by the Armed Forces Institute of Pathology to scattered collections in university departments across the United States.

"It is difficult for researchers to know what samples are out there, and what they need," explains Roger Aamodt, chief of the resources development branch at the National Cancer Institute (NCI). Aamodt's work compiling data on tissue samples from cancer patients helped form the basis for the broader Rand survey. "For the first time, the handbook puts this information in one public document."

Aamodt says there is "an incredible growth curve" in demand from researchers for human tissue samples, most of which were collected by pathologists without anyl intention that they would be used for research. But progress in genetics is turning these collections into powerful research tools. The Cooperative Human Tissue Network, which was established by the NCI in 1987 to obtain tissue samples for cancer researchers, distributed 50,000 samples last year to more than 500 investigators.
Aamodt suggests that the guide will be particularly useful for researchers at smaller institutions lacking specialist facilities to help their scientists find samples.

Rand started gathering information on US tissue sample archives for the National Bioethics Advisory Commission when it was preparing guidelines governing the circumstances in which the samples could be used in research. Many patients had not given informed consent to their samples being used in research, and there are concerns about the privacy of the genetic information they contain. The commission published its guidelines last year, and Rand has decided to publish the survey's results as a research tool.

Elisa Eiseman, the survey's chief author, says it should serve as a resource for basic and clinical research into many diseases. She adds that Rand is talking to the NCI and the International Society of Biological and Environmental Repositories about putting the survey's contents on the Internet. Colin Macilwain

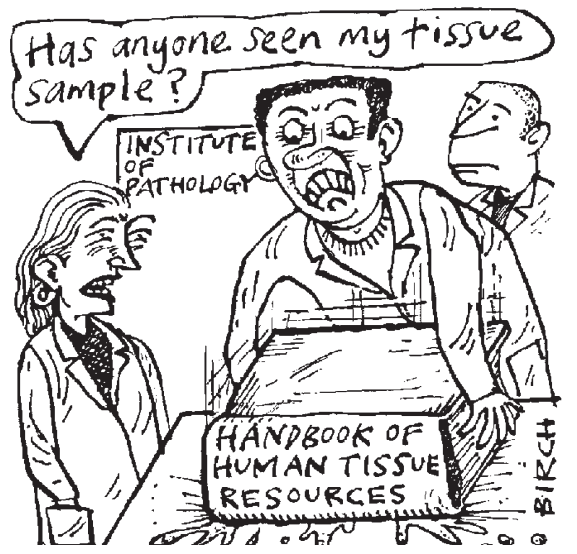

\section{India targets extra research funds}

\section{New Delhi}

A $\$ 500$ million annual increase for the next five years in funding for Indian science and technology, promised by prime minister Atal Behari Vajpayee, will be used to boost basic research, modernize laboratories, and launch new technology missions, according to officials in the science ministry.

Valangiman Ramamurti, secretary for the Department of Science and Technology, says the news "has come at a time when funding for even routine basic research was steeply on the decline and several good proposals from universities had to be turned down".

Earlier this month, Vajpayee said that his government, led by the Bharatiya Janata
Party, would provide funding worth 1 per cent of the gross domestic product for research and development in the financial year beginning 1 April 2000, increasing to 2 per cent in 2004 (see Nature 403, 126; 2000).

Ramamurti says that the heads of scientific agencies who met with finance minister Yashwant Sinha were given the impression that the increases would be reflected in the fiscal year 2000 budget.

According to Ramamurti, the additional resources would be spread across various scientific agencies under different ministries. At least 30 per cent would be used to boost basic research, with 20-30 per cent to go on "infrastructure creation". $\quad$ K. s. Jayaraman 